\title{
Progress Narratives, Racism, and Level Playing Fields: Recent Academic Literature on Sports ${ }^{1}$
}

\section{Michael Ezra}

SPORTS JUSTICE: The Law and Business of Sports. By Roger I. Abrams. Boston: Northeastern University Press. 2010.

AMERICAN HOOPS: U.S. Men's Olympic Basketball from Berlin to Beijing. By Carson Cunningham. Lincoln: University of Nebraska Press. 2009.

KING OF THE COURT: Bill Russell and the Basketball Revolution. By Aram Goudsouzian. Berkeley: University of California Press. 2010.

A LEVEL PLAYING FIELD: African American Athletes and the Republic of Sports. By Gerald L. Early. Cambridge: Harvard University Press. 2011.

Sports are ubiquitous in American society; their economic reach and cultural influence is pervasive. If one were to use annual revenues as the measure, as Fortune does in its yearly list of the nation's largest corporations, then in 2010 the National Football League would be around the top 250, Major League Baseball would be near the top 350, and the National Basketball Association would be just outside the top 500, had all their teams not been incorporated separately. Sports have always been entitled to a staggering share of American media, regardless of which medium has dominated. Sports are introduced to children whose becoming players and consumers at an early age is an essential aspect of their development. What does the prevalence of sports say about American society?

Sports provide a unique canvas for people to paint their version of an ideal America, since their meaning comes from the preservation of a level playing 
field that guarantees fairness, rewards merit, and yields just results. Sports are metaphorically ripe for comparison to America at its finest, and much of their cultural influence comes from the making of such meaning. Direct appeals to patriotism that might seem inappropriate elsewhere - consider that the national anthem is not played during your average movie preview - are encouraged within the sports world. Aggressive federal intervention into baseball's steroids scandal suggests the significance of the level playing field and the sense of outrage that accompanies its violation.

Race has played a central role in our understanding of sports and the level playing field. Racial inequalities run counter to America's grandest ideals, yet sports are where African American success has become a key aspect of the landscape. Ideologically, black success in sports can stand in for the real thing, as a counterpoint to the racial inequalities that are an outrageous violation of American society's supposed level playing field. Narratives that position sports as a proving ground for our national moral authority, with race at their center, reflect this patriotic and rhetorically progressive bent. Think of how the Jackie Robinson story is often told as one in which progressive elements win out over prejudice and racism.

It is quite common for writers, including those whose books are reviewed herein, to boil down sports to either a positive or negative force. Sports as good and sports as bad are predominant themes. Race is one of the key criteria used to carry this assessment, thus another version of the sports as good/sports as bad paradigm might be called the sports as racially progressive/sports as racist dichotomy. The theses of the four books reviewed are all gradations of these scales. Abrams and Cunningham present sports as a utopian site where the level playing field rules. Goudsouzian believes that sports have an ambiguous effect, paradoxically facilitating both the breakage and reinforcement of the color barrier. Early positions sports as a clearinghouse for racism. The major limitation of these lines of inquiry is that they do not produce any material understanding of how society works, but instead ultimately rely on the authors' value judgments to determine the meaning of sports.

$* * * * * * * * * * * * * * * * * * * * * *$

The dynamic described in Sports Justice between sports and the judicial system is a cause-and-effect one; whenever market forces corrupt the purity of sports, the courts will intervene to restore it. In the Abrams model, both sports and courts are level playing fields protected by rules. He writes, "This is a book about rules: the rules of the game, which ensure a level playing field within sports, and the rules of law which apply to the business of sports" (vii). He defines the courts as "the authoritative institutions which resolve the disputes that arise" (13). When describing how the courts overturn market-driven injustices, like in the case of Casey Martin's successful lawsuit to gain access to the PGA Tour, the model holds up and Abrams can plausibly celebrate the triumph of the level playing field. 
Overall, however, the uncritical portrayal of sports-as-utopia preserved by an impartial judicial system stifles the book's analytical scope. Abrams never explores the key question of why the courts have repeatedly placed sports outside the laws that govern the rest of us, often to the detriment of what he says they are supposed to do, which is protect the level playing field from market forces. On the contrary, the peculiar legal status of sports makes it vulnerable to discriminatory practices that can corrupt the ideal of the level playing field. Major professional sports leagues are protected by anti-trust exemptions that make it difficult for prospective rivals to compete. Big-time college sports forces athletes to refuse monetary compensation and any share of the revenues that might result from their labor. Abrams is aware that these injustices exist, but his model leaves him unprepared to analyze the court's complicity in creating them.

Nowhere is this clearer than when Abrams explains how the courts have adjudicated personal injury cases resulting from on-field incidents. The courts systematically have rejected claims brought by players, even those injured by illegal contact that anywhere else would be deemed assault. Victims of the most wanton attacks - you could be skating innocently back to the bench during a break in the action when you are suddenly clubbed repeatedly on the neck by an opponent's hockey stick, resulting in your permanent paralysis - almost never are recompensed. Abrams mourns court impotence in these cases, "There is no justice in a criminal law system that allows the travails of life and death to be determined by the commercial interests of profit" (131-132). But he fails to consider that the legal system's special handling of sports is what causes such problems to prevail.

After ignoring race for its duration, the book curiously concludes with a piece on Jackie Robinson to illustrate for readers "The most remarkable example of modern sports justice" (195). This was a strange choice, considering that his entrance into the big leagues was not decided by the courts. Abrams never explains why the Robinson case was so extraordinary, but the clear implication is that the black athlete evidences how race, sports, and the level playing field intersect to bring out the best America has to offer. One of the criteria of a sport, according to Abrams, is that there are clearly defined winners and losers. But what is missing from Sports Justice is any analysis of who benefits and who does not when sports justice prevails. After reading this book, one is left with an unrealistic model that presumes progress. There are no losers, only winners.

Carson Cunningham's American Hoops also positions sports as a progressive site, particularly basketball, whose simultaneous emphasis on teamwork and individual freedom bridges all kinds of cultural differences. In this model, basketball is assumed to be home to the level playing field, thus both its study and consumption will bring about positive change. American Hoops is plagued by this simplistic treatment of the sport, too often devoting space to details like how many fouls the U.S. committed in its early-round 1948 game against Egypt without exploring more important things. Cunningham concludes that the increased quality of Olympic basketball will make the world a better place because 
"the Olympics can enable the NBA to raise its level of play at home while offering a unique opportunity to build goodwill and visibility on the international stage" (413-414). The book's last words are merely a call for fandom, but they are indicative of the author's perspective:

So, to the individual sportsman, corporate employee, fan, political agitator, and consumer, whether watching Olympic basketball through traditional television broadcasts, streamlining broadband video over the Internet, receiving satellite signals beamed to a cell phone, or downloading images to an iPod: may we all continue to enjoy the action. It will be hard not to (414).

There is not much mention of race in this book, but when it comes up, the subject is guided by the prototypical Jackie Robinson story where good people successfully challenge racism. This trope appears during the author's discussions of Oscar Robertson and Mike Bantom, but the most notable example is his assessment of Bill Russell. The focus on Russell highlights how heroic agency within basketball's level playing field can transcend racial barriers. "Of course, despite the prejudice, the United States also offered Russell remarkable opportunitiesnot just for an African American but for anybody," writes Cunningham (101). Russell was the first black head coach in American major professional sports and also the NBA's highest-paid player. The author asserts that the level playing field made this possible, "If not for the ability of sports to function as a meritocracy, such a dramatic shift would have been unlikely" (101). This sentence encapsulates the thinking of the book. Sports are worth our interest because through them we can see progress and the best our society has to offer. The analytical scope of American Hoops is greatly limited by this kind of thinking.

Aram Goudsouzian's King of the Court is the best of the books reviewed. It is well written and well organized, taking us through Russell's life in a thoughtful and interesting manner. Goudsouzian deserves credit for doing the necessary research and then crafting a readable narrative that sheds new light on Russell by putting his story into a sociopolitical context beyond sports. King of the Court is punctuated by interviews that add colorful detail (as is American Hoops, by the way) and employs an impressive range of sources. Goudsouzian draws upon the progressive level playing field for analysis, but his knowledge of African American history and culture steers him toward more sophisticated content than the other authors.

King of the Court struggles to make meaning of race, though, ultimately bowing to the dominant portrayal of Russell as a heroic and transcendent agent. The author settles disappointingly on W.E.B. Du Bois's double consciousness ${ }^{2}-$ updated to reflect the contemporary black freedom struggle's black power/civil rights dichotomy - to explain Russell's meaning. "He cherished an integrated community, and he raged with separatist impulses. While flowing with the black 
political tide, he charted new waters for the black athlete," writes Goudsouzian (149). Iterations of a doubly-conscious Russell who was at the vanguard of progress can be found throughout the book. While plausible, these conclusions do not match the ambitiousness of the rest of the project, and give readers little sense of what Russell's life really means. That an otherwise solid book would fail in this regard raises questions not about the author's competence, but of the viability of the progress narrative for assessing the black athlete's significance.

Although skeptical toward the progress myth, Gerald Early so uncritically positions sports as a site of racism that The Level Playing Field crumbles under an onslaught of implausibility - not to mention the galling assuredness that accompanies it - that could only make sense when shoehorned into the narrow interpretative frameworks the author dreams up. Almost all of the speeches, magazine pieces, and essays that make up this short collection of Early's recent works wind up in the same place, that sports carry social injustice and racism, repeatedly reducing complex issues to morality plays featuring black rebel heroes against hegemonic white racists. The Level Playing Field rarely gets beyond superficial critique, some of which can be exploded without much effort.

One of the book's many puzzling moves is its cramming of boxer Naseem Hamed, a British-born Muslim with Yemeni parents, into a model that reinvents his defining moments as a series of amateur bouts where Early alleges that as a teenager, "Hamed received his most racist receptions when fighting a local boy on that boy's turf" (219). Early's interpretation of Hamed rests upon this claim that cannot be proven, measured, documented, or otherwise be understood as much but a grab that allows Early to get down to the business of making Hamed into a black race rebel who was a lightning rod for white racism. Why else, in a piece whose goal is to make meaning of the fighter's cultural impact, would Early ignore Hamed's professional career and instead focus on obscure amateur matches that happened a decade prior to Hamed's rise to prominence? The problem is that Hamed's title bouts, which are of course the texts that really matter, revealed that he "was probably the most loved Arab in England, and far and away the most popular boxer there" (214). This opportunity to dig in and interpret Hamed's significance instead is vapidly dismissed in a half sentence as "an ironic form of assimilation" (214).

Early hinges his analysis on generalizations that too often do not hold up to scrutiny. His egregious misinterpretation of Curt Flood's challenging baseball's reserve clause begins with the questionable premise that the case lacked resonance for African Americans because "if Flood failed, then there was nothing much at stake for blacks at large," (104) so therefore "Flood would be more the darling of the white liberal Left than he would ever be of the black civil rights establishment or of black nationalist-minded thinkers" (104). The sloppiness of these sweeping statements aside, a closer look reveals that black newspapers, civil rights leaders, and black power activists all advocated for Flood. Early ignores that Flood's black contemporaries took seriously the significance of his 
heading a progressive, but not black-specific, fight for labor rights in a site as important as baseball. ${ }^{3}$

Early's most plausible conclusions appear when he stays within the familiar territory of double consciousness. While they reveal nothing beyond the same old paradigms about sports and progress, at least they make sense. The 1997 celebration of the fiftieth anniversary of Jackie Robinson's breaking the color line in baseball, asserts Early, reveals our preoccupation "with ourselves and our own dilemma about race, a problem that strikes us simultaneously as being intractable and 'progressing' toward resolution" (185). He adds that "In the end Robinson as tragic hero represented, paradoxically, depending on the faction, how far we have come and how much more needs to be done" (186). These somewhat generic iterations reveal not just the limitations of Early's recent work, ${ }^{4}$ but more importantly with the area of race and sports as a whole, especially its entanglement with the progress narrative.

$* * * * * * * * * * * * * * * * *$

Sports are ripe for scholarly analysis, but much of the field is held back by an insistence upon using them to assess national morality. This approach is resistant to research and usually comes down to little more than the author's ideology. What is particularly troubling for the genre of race and sports is that so much of it is preoccupied with this very perspective. What is the Jackie Robinson story if not one about progress? As a result of this focus, we are left with various reiterations of double-consciousness, which was introduced over a century ago. The updating of Du Bois's original American/Negro paradigm into the more recent civil rights integrationist/black power nationalist spectrum does little to expand the model. Neither does its latest version, the one that sees Michael Jordan as either a transcendent cultural ambassador or a million-dollar slave.

The insidiousness of this is that the question of progress looms so temptingly as the most important thing that authors about sports are supposed to contend with, especially when turning to the black athlete. Studying how sports today depart from their counterparts of yesteryear, however, is a dead end; a sucker bet that rarely holds up to its promise to yield groundbreaking and convincing conclusions. That scholars are still spending much energy on such comparisons illustrates the difficulties our society has had defining racial advancement in a post-civil-rights era that can no longer identify integrative firsts as the measure. Looking back toward a heroic past to define the black athlete today only leads to declension narratives that leave us with more sellouts than race rebels. One of the valuable things about studying sports is that it can provide meaningful definitions of black life that contribute to a greater understanding of U.S. history and society. Much of the current coverage of race and sports, however, blatantly misinterprets what it means to be African American.

I dealt with this very conundrum in my book Muhammad Ali: The Making of an Icon, which unpacked how various publics have made meaning of the fighter 
throughout his fifty-plus years in the spotlight. The ultimate challenge was to encapsulate these processes under a plausible thesis that was not only based on research and argumentation, but also tensile and flexible enough to hold up under the floodtide of available information about Ali that could render it faulty. I wanted to do this without reducing Ali to symbolism that depended upon a value judgment to make sense. I instead wanted readers to gain greater meaning about how society works through an analysis of the economic implications of Ali's career. I wanted readers to come away with a model that they could use to actively understand what Ali means today, or at any time during his life, through their engagement with whatever texts are available to them.

What I found is that in order to capably study Ali's impact, race was often the thicket I needed to untangle rather than cultivate. Casting aside race altogether would deform Ali's meaning, but putting it into a less precise framework than something through which to measure progress or racism is what made it useful. To understand the significance of the black athlete, race should be a means to an end, a line of inquiry that allows you to go further rather than a signal that you have reached your analytical endpoint. Reducing the black athlete to a symbol of progress or racism usually leaves us with double-consciousness and all its permutations.

When exploring Ali, there are myriad opportunities to get sidetracked into conversations that are set up to illustrate how Ali represented resistance to white racism or was a race man or was a symbol of the civil rights zeitgeist. As endpoints these theses do not teach you about how society works. When used to help construct a larger thesis, however, as a backdrop that helps the main narrative - that the commercial and cultural aspects of Ali's career were related - to go forward, race takes on powerful analytical context:

As an eighteen-year-old southern black arriving on the national scene, Cassius Clay [he later changed his name to Muhammad Ali] faced pressure to understand and articulate himself in relation to the civil rights movement. By the time he turned professional, the black freedom struggle was firmly entrenched in the news and culture and influenced how people understood who he was. In calculating how his public persona would affect his professional life, particularly his ability to make money, Clay and his advisers had to estimate how best to respond to these developments. ${ }^{5}$

Assessing these responses means not only understanding the time period, but knowing what was being said and done about Ali and by Ali and on his behalf, in addition to gathering the economic particulars. One cannot skip race if they want to understand what Ali means, but one cannot stop there, either. Once the reader understands that the civil rights movement was an important part of the 
landscape, I feel comfortable moving on until the next moment comes along when the racial context needs to be explained.

My discovery that Ali's transformation from a controversial to a revered figure was tied to the commercial dynamics of his career came from the close study of the actual financial data surrounding him. This research gave me license to argue plausibly that the most important factor driving shifts of public opinion toward Ali was who was profiting from their associations with him. Because so much of it reduces him to a racial symbol, however, most previous work about Ali had considered only his political, cultural, and professional works - refusing to be drafted, joining the Nation of Islam, beating George Foreman - to be the basis for his legacy. But digging beyond race reveals that all of these events had economic implications that proved crucial to their larger meaning. At the very heart of public opinion toward Ali were not necessarily these actions, but their financial consequences. Only when pushing beyond the symbolic toward the material could I figure this out.

The failure to analyze black athletes through meaningful frameworks besides race has smothered what should be a more vibrant site of investigation. The Ali story has atrophied into a generic rendition of the progress narrative starring the fighter as the transcendent race man turned hero for all humanity. It is not too different from the Jackie Robinson story. But there is use in this development, namely through the study of how the Ali story and others like it use race to construct historical memories based on ideas of progress and universal humanism that are repackaged into ideological content, consumer goods, and other cultural products. But Ali narratives never take these kinds of turns when authors primarily pursue his symbolic meaning. Race and progress must be a part of a longer list of analytical categories used to deal with the Ali legend. While one should not ignore them as critical factors in telling the story of the black athlete, they should be used as a means to something else. Useful analyses of race, progress, and sports that show us how society works will come when authors give us more material and less symbolic accounts of these relationships.

\section{Notes}

1. I use "sports" instead of "sport" to refer to the institution as a whole. Sports will be used as both singular and plural.

2. Du Bois introduced his idea of African American double-consciousness in an 1897 Atlantic article: "It is a peculiar sensation, this double-consciousness, this sense of always looking at one's self through the eyes of others, of measuring one's soul by the tape of a world that looks on in amused contempt and pity. One feels his two-ness, - an American, a Negro; two souls, two thoughts, two unreconciled strivings; two warring ideals in one dark body, whose dogged strength alone keeps it from being torn asunder. The history of the American Negro is the history of this strife."

3. Abraham Iqbal Khan, Curt Flood in the Media: Baseball, Race, and the Demise of the Activist Athlete (Jackson: University of Mississippi Press, 2011) challenges Early's interpretation of Flood's meaning and provides much of the perspective for this paragraph.

4. For a more complimentary assessment of Early's work from this period, see my favorable review of his This is Where I Came In: Black America in the 1960s (Lincoln: University of Nebraska Press, 2003) in Journal of African-American Studies 8:3 (Winter 2004): 71-72.

5. Michael Ezra, Muhammad Ali: The Making of an Icon (Philadelphia: Temple University Press, 2009), 9. 